\title{
NECROZA TUBULARĂ ACUTĂ PRIN ACȚIUNEA NEFROTOXICĂ MEDICAMENTOASĂ - CAUZĂ RARĂ DE SINDROM NEFROTIC LA COPIL
}

\author{
Magdalena Stârcea1,2, Mihaela Munteanu², Radu Russu², Anca Iulia Rotaru², \\ Doina Mihăilă $\breve{3}^{3}$ Ingrith Miron ${ }^{1,2}$ \\ ${ }^{1}$ Universitatea de Medicină şi Farmacie „, Gr. T. Popa “, Iaşi \\ ${ }^{2}$ Secția de Nefrologie Pediatrică, \\ Spitalul Clinic de Urgență pentru Copii ,,Sf. Maria“, Iaşi \\ ${ }^{3}$ Laboratorul de Anatomie Patologică, \\ Spitalul Clinic de Urgență pentru Copii ,,Sf. Maria “, Iaşi
}

\begin{abstract}
REZUMAT
Sunt prezentate două cazuri de sindrom nefrotic (SN) indus de medicamente cu nefrotoxicitate la nivel tubular, cu evoluție diferită în contextul maladiilor incriminate etiologic.

Fetiță în vârstă de 5 luni, internată cu SN (dovedit clinic şi biologic) şi insuficiență renală acută, după o spitalizare în alt servici pentru bronhopneumonie. Fetița a fost tratată cu ceftriaxonă şi gentamicină 12 zile. Suspiciunea de SN congenital a fost înlăturată de evidențierea necrozei tubulare renale în fază de recuperare (biopsie renală). Evoluția a fost favorabilă în 7 zile sub dializă peritoneală.

Adolescentă de 16 ani cu boală Basedow tratată de 3 ani cu carbimazol. S-a prezentat cu sindrom nefrotic care nu a fost influențat de corticoterapie. Examenul histopatologic a evidențiat necroză tubulară toxică, fibroză interstițială, absența leziunilor glomerulare. A fost sistat tratamentul nefrotoxic, s-a practicat tiroidectomie după care edemele s-au redus, dar funcția renală a continuat să se deprecieze, în condițiile terapiei nefrotoxice administrată timp de 3 ani.

Concluzii. Necroza tubulară renală exprimată clinic şi biologic prin sindrom nefrotic, însoțit de insuficiență renală este o situație rară la copil; gentamicina şi carbimazolul pot fi incriminate etiologic. Suferința renală poate fi ameliorată sau nu prin înlăturarea medicamentului cauzal. Eşecul terapeutic s-a corelat cu durata agresiunii medicamentoase şi evoluția unor comorbidități.
\end{abstract}

Cuvinte cheie: necroză tubulară, sindrom nefrotic, insuficiență renală acută

Multiple terapii determină efecte adverse renale. Cea mai comună formă de prezentare este insuficiența renală acută prin necroză tubulară acută. Există situații, mai rar citate, în care necroza tubulară poate îmbrăca altă formă de manifestare clinico-biologică, anume sindromul nefrotic (1).

\section{Cazul I}

Sugar, de sex feminin, în vârstă de 5 luni, transferat din altă unitate sanitară pentru edeme generalizate şi retenţie azotată. Fără antecedente familiale sau personale patologice semnificative până în acel moment, copilul a fost internat pentru bronhopneumonie cu evoluție trenantă sub tratament antibiotic (12 zile de cefalosporină + Gentamicină). La o zi după externare revine cu paloare, febră, vărsături alimentare, meteorism abdominal, scaune semiconsistente, iar după 2 zile apar edeme generalizate, se decelează anemia şi retenția azotată, motiv pentru care se transferă în clinica noastră. Examenul clinic la internare obiectivează starea generală influențată, afebril, agitat. Se remarca paloarea cutaneo-mucoasă, edeme generalizate, oliguria $(0,23 \mathrm{ml} / \mathrm{kg} / \mathrm{h})$.

Diagnostic de etapă a implicat:

- Sindromul hemolitic şi uremic, dar sugarul asocia doar anemie normocromă, normocitară, cu reticulocite normale, fără schizocite şi cu plachete normale $\left(\mathrm{PLT}=543.000 / \mathrm{mm}^{3}\right)$. 


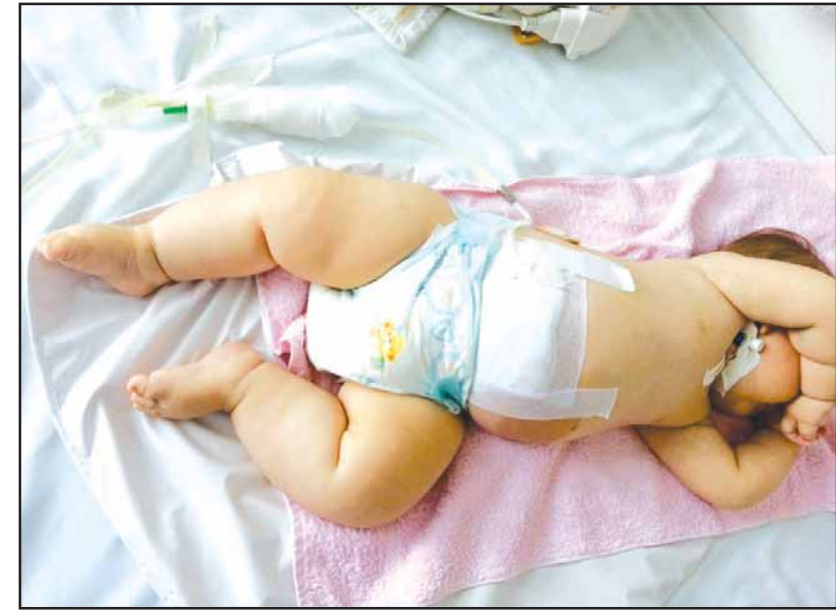

FIGURA 1. Edeme generalizate

- Pielonefrită acută asociată unei eventuale malformații urinare la sugar - exclusă de urocultura sterilă şi ecografia reno-vezicală care nu evidenția elemente malformative

- Sindrom nefrotic în condițiile în care pacienta asocia dislipidemie, hipoproteinemie marcată, hematurie, proteinurie.

Testarea negativă pentru virusurile hepatitice B şi $\mathrm{C}$ a exclus un sindrom nefrotic secundar acestora. Dată fiind vârsta mică s-a suspicionat un sindrom nefrotic congenital, fiind necesară pentru confirmare evaluarea morfologică.

Degradarea brutală şi rapidă a funcției renale (uree $=114 \mathrm{mg} / \mathrm{dl}$, creat $=4,16 \mathrm{mg} / \mathrm{dl}$, hiperuricemie - 7,9 mg/dl) până la un clearance de creatinină de $6,6 \mathrm{ml} / \mathrm{min} / 1,73 \mathrm{~m}^{2}$, precum şi acidoza metabolică refractară la terapia medicamentoasă au impus plasarea unui cateter de dializă peritoneală pentru începerea epurării extrarenale. $\mathrm{Cu}$ acea ocazie s-a practicat şi biopsia renală intraoperatorie. Aceasta a evidențiat tubi renali proximali cu modificări degenerative de tip granulocitar, focare de necroză parcelară, imagini de regenerare, specifice necrozei tubulare acute postmedicamentoase.

Diagnostic pozitiv a fost de Necroză tubulară acută postmedicamentoasă, Insuficiență renală acută, Sindrom nefrotic secundar, Anemie secundară. Tratamentul a constat în corecția tulburărilor electrolitice şi acido-bazice, corectarea anemiei prin transfuzii de masă eritrocitară izogrup, izo Rh, corectarea hiperuricemiei cu Allopurinol, precum şi epurare extrarenală prin Dializă peritneală menținută 10 zile, bine tolerată. Evoluția a fost lent favorabilă, cu reluarea diurezei şi scăderea retenției azotate. Controalele ulterioare au relevat dispariția tabloului clinico-biologic de sindrom nefrotic si normalizarea parametrilor renali.

\section{Cazul II}

Adolescentă de 15 ani care se prezintă cu edeme generalizate, creştere bruscă în greutate, în aproximativ o săptămână. A fost diagnosticată în 2012 (la vârsta de 13 ani) cu Boală Basedow, Exoftalmie medie, Amenoree secundară la Institutul Național de Endocrinologie „C.I. Parhon“, Bucureşti. Aflată în tratament $\mathrm{cu}$ Carbimazol şi intermitent $\mathrm{cu}$ Euthyrox (pentru episoadele de hipotiroidie asociate) dezvoltă brusc edeme generalizate. Examen clinic obiectiv la internare releva stare generală bună, spor ponderal $10,5 \mathrm{~kg}$ față de internarea anterioară (în urma cu 2 luni). Asocia facies dismorfic pe seama exoftalmiei, edeme generalizate. Era normotensivă, echilibrată cardio-pulmonar, cu exoftalmie bilaterală, guşă gr I OMS, elastică, omogenă, mobilă, nedureroasă. Biologic s-a confirmat as-
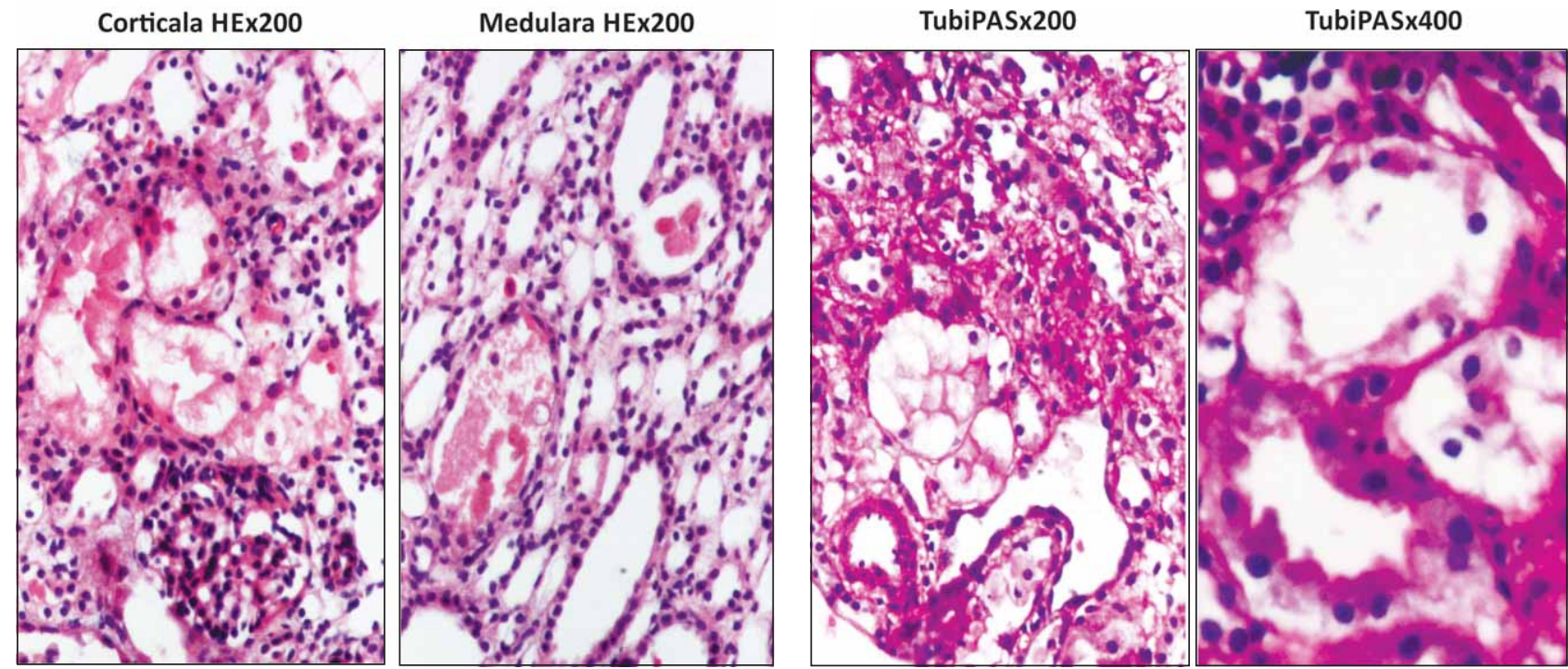

FIGURA 2. Degenerescență granulocitară tubulară, necroză parcelară, glomerul de aspect normal, inflamație interstițială 


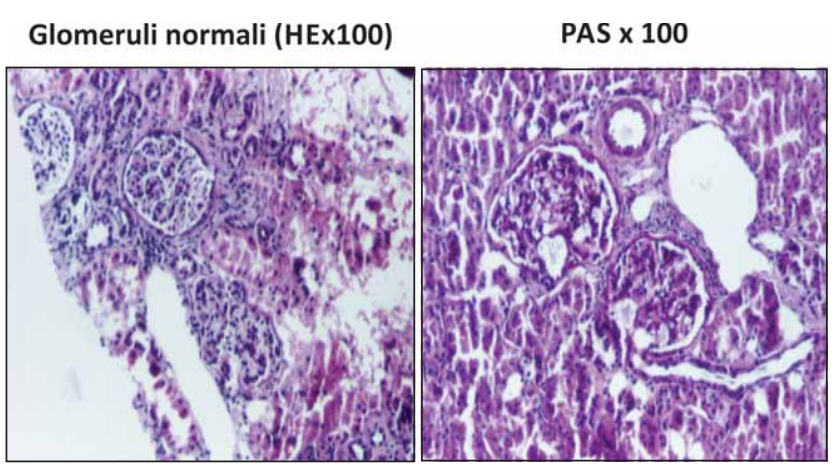

Necroza tubulară + focar de fibroză ineterstițială SZ x 200
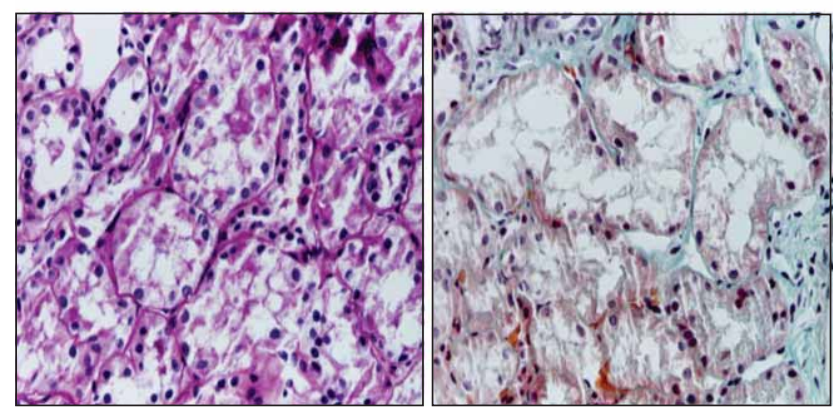

FIGURA 3. Glomeruli normali, necroză tubulară, fibroză interstițială

pectul tipic de sindrom nefrotic impur (sindrom inflamator, hipoproteinemie 35,07 g/1, hipoalbuminemie, hipogammaglobulinemie, dislipidemie cu hipercolesterolemie $656 \mathrm{mg} / \mathrm{dl}$ şi hipertrigliceridemie $474 \mathrm{mg} / \mathrm{dl}$, proteinurie $3 \mathrm{~g} / \mathrm{l}$, hematurie $3+$ ). $\mathrm{S}$-au luat în discuție cauze secundare de sindrom nefrotic la adolescente, fiind evaluați $\mathrm{Ag} \mathrm{Hbs}, \mathrm{Ac}$ HVC, HIV, RPR - negativi. Intradermoreacția la tuberculină a fost negativă. AAN, celulele lupice, profilul ANA 9 şi C3 - în limite normale au exclus o boală sistemică. Parametrii tiroidieni erau in limite normale la acel moment. În acel stadiu s-a opiniat pentru diagnosticul de Sindrom nefrotic primitiv impur, Boală Basedow, Exoftalmie formă medie. S-a inițiat terapie imunosupresivă în schema cortizonică clasică, dar lipsa de răspuns a impus iniţierea schemei Mendoza. Pentru elucidarea morfologică s-a practicat biopsia renală percutană. Aceasta a evidențiat Imunofluorescență negativă, iar la parafină leziuni glomerulare minime, tubi renali contorți cu arii de degenerescență vacuolară, focare de necroză celulară alături de atrofie tubulară şi fibroză interstiţială. Concluzia a fost de necroză tubulară toxică, cronică, activă.

Concomitent s-a înregistrat declinul funcției renale (RFG după Schwartz - $52 \mathrm{ml} / \mathrm{min} / 1,73 \mathrm{mp}$ ). $\mathrm{S}$-a impus sistarea terapiei nefrotoxice cu antitiroidiene şi tiroidectomie în urgență. Ulterior, după o săptămână de la intervenția chirurgicală, edemele s-au remis, dar funcția renală a continuat să se deprecieze. Menținea dislipidemie, proteinurie şi hematurie, necesitând monitorizare.
Ambele cazuri ilustrează efectul toxic tubular renal al unor droguri utilizate în terapia pediatrică antiinflamatorii nonsteroidiene (1), aminoglicozide (2), Vancomicină (3), substanțe de contrast, săruri de aur. Particularitatea constă în expresia clinicobiologică a necrozei tubulare acute ca sindrom nefrotic. În primul caz în care expunerea la toxic a fost de scurtă durată, evoluția a fost cu recuperare integral a funcției renale, față de cel de-al doilea caz în care evoluția a fost spre fibroză interstițială deoarece toxicul a acționat mult mai mult timp. În literatură sunt citate numeroase cazuri de nefrită tubulo-interstițială toxică după terapia cu aminoglicozide $(2,4)$. A fost raportat un singur caz (bărbat de 72 ani) cu nefrită interstițială după administrarea Carbimazolului (5), fiind cunoscută până în prezent doar legătura între propylthiouracil şi afectarea renală.

\section{CONCLUZII}

Secunoaşterolulnefrotoxic al aminoglicozidelor. Carbimazolul a fost incriminat doar în câteva cazuri de necroză tubulară. În foarte rare situații un trigger nefrotoxic determină aspect clinico-biologic de sindrom nefrotic. Suferința renală poate fi ameliorată sau nu prin înlăturarea medicamentului cauzal. Eşecul terapeutic s-a corelat cu durata agresiunii medicamentoase şi evoluţia unor comorbidități. 